\title{
Student Attitudes Against Academic Cheating and Orientation of Learning Objectives Viewed from the Class Level
}

\author{
Yaya Sunarya \\ Educational Psychology and Guidance \\ Universitas Pendidikan Indonesia Bandung \\ yayasunarya@upi.edu
}

\begin{abstract}
Orientation of students' learning goals directs to the process and learning strategies that they use. The orientation of the goal of learning performance often makes students go for academic cheating to get high scores. This study aims to describe the attitudes of middle school students towards academic cheating and the orientation of their learning objectives in terms of their grade level status. The results showed that: (1) students generally had an attitude of justification for academic cheating; (2) students have mastery learning goal orientation; (3) there are significant differences in attitudes towards academic cheating both in terms of class level and parental demographic status; (4) there is a significant difference in attitudes toward academic cheating seen from the orientation of their learning goals, and (5) there is no significant difference in orientation towards learning objectives in terms of class level and parental demographic status; Based on the results of the study, counseling teachers are expected to be able to provide basic services to develop resistance to academic cheating; and responsive services to develop mastery learning goal orientation for students who have performance learning goal orientation.
\end{abstract}

Keywords: attitudes towards academic cheating, learning objective orientation, student attitudes

\section{INTRODUCTION}

Cheating is the most common academic cheating done by students in schools today. This phenomenon does not only occur in Indonesia but occurs in various countries (Springer.com, 2018; Hu and Sun, 2017; Hu and Lei, 2016; Anderman and Koenka, 2017). Cheating behavior has a close relationship with learning goals that will be a direction for their activities in school (Diego, 2017). As Ames said (Schunk, Pintrich, \& Meece, 2008), the orientation of learning objectives is an integrated pattern of beliefs, which leads to different ways in the process, behavior, and responsibility of a person to achieve his learning goals. The purpose of education basically leads to positive changes both in the cognitive (knowledge), affective (attitude and value), and psychomotor (skill) aspects. But in reality, there are still many students, teachers, and parents who only prioritize learning outcomes in the form of high scores in each subject regardless of how the achievement process is carried out.

To examine this, Bernard E. Whitley, Jr. (1998), conducted a study over a 10-year period and found 107 cases. Academic cheating will have a further impact, not only on students as a form of moral deterioration in schools, but also on the decline in the quality of education and contribute to the formation of a generation of plagiarism. To reduce this the school has made various rules about the prohibition of cheating.

Academic cheating, especially cheating, arises beginning with a negative view of the achievement of success and learning goals, and then presses on various aspects of life including pressure from teachers and surrounding communities (Salter, Guffey and McMillan, 2001; Sarita and Dahiya, 2015). A person's attitude towards something will be related to the purpose of life that he lives. What is the real attitude of students towards cheating, as well as the direction of their learning orientation? It needs to be researched and explored from various sides, so that the development model can be made.

\section{LITERATURE REVIEW}

There are two categories in learning goal orientation, namely mastery learning goal orientation which emphasizes mastery achievement and competency improvement, and performance learning goal orientation which emphasizes the relative evaluation of competencies or achievement achievements of others (Ormrod, 2000)

Referring to the theory, students with mastery learning objective orientation have the following characteristics: (1) believe that competence can develop through practice and effort; (2) choosing tasks that can maximize opportunities for learning; (3) react to easy tasks with feelings of being bored and disappointed; (4) view business as something important to improve competence; (5) more intrinsically motivated to learn the subject matter; (6) presenting more self-regulated behaviors and learning; (7) using learning strategies that lead to a true understanding of the material; (8) evaluates own performance within the framework of the progress that has been made; (9) views mistakes as normal and useful parts in the learning process, and utilizes mistakes to help improve performance; (10) feel satisfied with performance if you try hard, even if the business fails; (11) interpret failure as a sign that more effort is needed; and (12) views the teacher as a resource and guide to help individuals learn. Students with orientation toward learning performance goals have the following characteristics: (1) believe that competence is a stable characteristic. Some people have it and some don't; (2) 
choosing a task that maximizes the opportunity to demonstrate competence, avoiding tasks and actions (eg asking questions) that make it look incompetent; (3) react to easy tasks with pride; (4) views business as a sign of low competence, assuming that competent people should not need to try hard; (5) are more extrinsically motivated, such as reinforcement and external punishment, and tend to cheat to get high scores; (6) lack of self-regulated learning attitudes and behaviors; (7) using learning strategies that are only rote learning (for example repetition, copying, remembering word for word); (8) evaluating performance in terms of comparison with others; (9) views mistakes as a sign of failure and incompetence; (10) are satisfied with performance only if successful; (11) interprets failure as a sign of inadequate ability and therefore predicts repeated failure in the future; and (12) views the teacher as an assessor, giftgiver or punishment. With such characteristics, students with an orientation to the goal of learning performance often feel pressured and provoked to do everything in order to get high grades, including by committing academic cheating.

Academic cheating is cheating or attempts made by students to use methods, tools, and resources that are not allowed to do academic work. Cheating is often done by students so that they can get good grades and achievements and make them proud in the eyes of others, especially teachers and / or their parents, by ignoring the achievement of understanding and competence of the subject matter delivered, (Lambert, Hogan, and Barton 2003). The encouragement will encourage the emergence of certain attitudes that can be measured through: (1) a person's response to conditions that allow for fraud, (2) responses to specific examples that might or might not be considered cheating, (3) attitudes towards perpetrators of fraud, (4) attitude towards cheating morality, and (5) attitude towards teacher behavior (Gardner \& Melvin, 1988)

Referring to Piaget's theory of cognitive development (Makmun, 2007), there are four factors that can influence an individual's cognitive development by changing their thought processes, namely biological maturity, physical activity, social experience, and equilibrium. This will change with age and length of study (Yusuf, 2003). Thus, grade level can form a certain attitude towards cheating.

\section{METHOD}

This research uses a quantitative approach with a comparative method. The population in this study were students in classes VII, VIII, and IX. Data collection instruments in the form of a questionnaire: (1) the scale of orientation of learning objectives whose construct is developed by Ormrod (2000), in the form of paired comparisons; and (2) the attitude scale towards academic cheating is adapted from the Attitude Toward Cheating Scale (ATC scale) made by Gardner \& Melvin (1988). Data analysis, carried out with the One Way Anova test.

The subjects of this study were junior high schools in Bandung regency, totaling 302 students, with details of 103 class VII people, 101 class VIII students and 98 class IX students.
The scale of the orientation of the learning objectives is arranged referring to the orientation of the mastery learning objectives and the orientation of the learning objectives of performance. This scale is in the form of paired comparison. In this scale, each indicator is broken down into 5-6 items, and the number of all items is 66. Through this scale, it can be seen whether students have mastery or performance learning orientation.

The attitude scale towards academic cheating is adapted from the Attitude Toward Cheating Scale (ATC scale) made by Gardner \& Melvin (1988). This scale consists of 31 statement items, 12 items containing statements that show opposition to academic fraud, and 19 other items containing statements that show justification for academic fraud. This instrument is in the form of a Likert scale with 5 response choices, strongly agree (SS), agree (S), doubt (R), disagree (TS), and strongly disagree (STS). Through this scale, it can be seen whether students have an attitude of justification or opposition to academic cheating.

Data analysis, begins with the static assumption test to determine the appropriate statistical methods and analytical techniques. Statistical test results show that the data are normally distributed and homogeneous. Therefore, the parametric statistical method can be used. Next, the comparison test. Learning objectives and attitudes towards academic cheating between students in grades VII, VIII, and IX, with the One Way Anova technique. Furthermore, to test the differences in attitudes toward academic cheating between students who have mastery learning goals and performance orientation, a Ttest is used for free samples or Independent Samples $\mathrm{T}$ Test. Comparison of this comparative test was carried out with SPSS software version 23.

\section{RESULT AND DISCUSSION}

The results of data processing on the orientation of learning objectives of junior high school students show an average value of 44.38 and a standard deviation value of 7.440. The average value is $>33$, and based on the criteria of grouping data included in the category of mastery learning goal orientation. These data, illustrate that in general students have mastery learning goal orientation, with details as much as $90.03 \%$ of students are in the mastery learning goal orientation category, and as many as $9.97 \%$ of students are in the performance learning goal orientation category (Table 1).

That is, the majority of students believe that mastery and competency enhancement are important in learning. The integration of these beliefs then raises the patterns that underlie them to have certain learning goals, and becomes a reason for them to show certain behaviors in achieving their learning goals. Judging from the data of each grade level, it is known that there is no significant difference in the average value between grade VII, grade VIII, and class IX students. All three class ranks are in the mastery learning goal category.

According to Schunk, Pintrich, \& Meece (2008), the characteristic of individuals who have mastery learning goal orientation is to study seriously and have confidence that mistakes are part of the learning process. In their 
behavior to achieve achievement, students with a high level of mastery learning goal orientation will focus more on the learning process, developing new skills, increasing or developing competencies, achieving a challenging thing, gaining understanding or insight, and mastering tasks in accordance with standards self-established and developed.

Table 1

Orientation of Learning Objectives

\begin{tabular}{|l|c|c|c|c|}
\hline & VII & VIII & IX & Total \\
\hline Mean & 44,90 & 43,56 & 44,66 & 44,38 \\
\hline Std. Dev & 7,42 & 7,61 & 7,27 & 7,44 \\
\hline$\sum$ Mastery & 93 & 88 & 90 & 271 \\
\hline$\%$ Mastery & 90,29 & 88 & 91,84 & 90,03 \\
\hline E Performance & 10 & 12 & 8 & 30 \\
\hline \% Performance & 9,71 & 12 & 8,16 & 9,97 \\
\hline
\end{tabular}

The results of this study can be used as a basis in determining the teaching system for students. Appropriate assessment model applied to students the current model is a benchmark reference assessment approach (PAP) model, this model can be an appropriate and effective step in the learning process of students.

According to Makmun (2007), the learning process oriented to the principle of mastery learning must begin with mastery (mastery) in the smallest part, then it can then be continued into the next unit (module) or unit. Through this mastery learning teaching system, achieving high levels of mastery of learning outcomes in students will make them have a healthy mental attitude. This is in accordance with Permendikbud No. 4 of 2018 concerning Assessment by the Education Unit and by the Government.

The results of further analysis are of a small proportion of research subjects (students) who have an orientation towards learning performance $(9.97 \%)$. That is, they still believe that a relative assessment of the competencies or achievements of others is important in learning. They believe that what is important is not the value of learning outcomes, but they believe that what is important for them is that they can apply the learning outcomes to their lives.

Suprayogi (2007) in his research explained that the orientation of students' learning goals can be influenced by personal factors which include setting or accepting goals from others, gender, and self-efficacy, as well as environmental factors that include parents, ethnic groups, and class climate.

The results of this small part of the study, if it is associated with factors that influence the orientation of students' learning goals according to Suprayogi (2007), it appears that men have a higher tendency to have a goal orientation of learning performance in themselves than women, is very appropriate. Furthermore, the work and education of parents who are not too high is very likely to influence their mindset in determining the educational goals for their children, so that it can affect the orientation of learning goals possessed by their children, in this case are students.

If the results of the above research, related to the condition of our society today, are very appropriate. Many parents are trying to find value, learn for value, bribe their bribe for value. This means that parents' efforts greatly affect children's lives and thinking patterns, learning is to achieve value, not to seek knowledge.

\section{Attitudes towards Academic Cheating}

Based on the results of data processing attitudes towards academic cheating on students, the following data are obtained (Table 2). The Table 2 shows a total average value of $84,353>82,353$, and based on data grouping criteria included in the category of justifying the existence of academic cheating. This means, in general $(59.47 \%)$ students have a "justifying" attitude towards academic cheating, and as many as $40.53 \%$ others "oppose" academic fraud. That is, most of them justify the existence of academic fraud, or are identified as having a high tendency to commit such actions.

Table 2

Attitudes towards Academic Cheating

\begin{tabular}{|l|c|c|c|c|}
\hline & Attitudes towards Academic Cheating \\
\hline & VII & VIII & IX & Total \\
\hline Rata-rata & 80,626 & 85,349 & 87,254 & 84,353 \\
\hline Std. Dev. & 10,20 & 9,54 & 7,90 & 9,67 \\
\hline$\sum$ Justify & 45 & 61 & 73 & 179 \\
\hline \% Justify & 43,69 & 61 & 74,49 & 59,47 \\
\hline$\sum$ Against & 58 & 39 & 25 & 122 \\
\hline \% Against & 56,31 & 39 & 25,51 & 40,53 \\
\hline significance & \multicolumn{5}{|c|}{0,000} \\
\hline
\end{tabular}

Furthermore, the results of the average score test showed that there were significant differences in attitudes towards academic cheating between students in class VII, class VIII, and class IX. Judging by the average value smaller than 82,353 . This figure shows that they have a resistance to academic cheating, while the average grade of students in grades VIII and IX that are greater than 82,353 shows that in general, they have a justifying attitude towards academic cheating. This means that class IX students are more justified in academic cheating, which means they have a higher tendency to commit these actions compared to class VIII and class VII students who generally oppose academic cheating.

Academic cheating (cheating, etc.) is something that academics need to avoid, because it is an act that is not commendable. The higher the level of one's education (grade level, etc.), the better the person's mindset must be. Therefore, the attitude should also be more positive, the better. In line with cognitive development theory, grade IX junior high school students whose biological maturity, physical activity, social experience, and equilibration are better than class VII and VIII students, so they are able to think more wisely in determining their attitudes and behavior, and have a better ability to understand the impact of the attitudes or behaviors that arise, including in terms of academic cheating, so they should be able to have an attitude against academic cheating.

In addition, judging from the characteristics of moral development, ideally junior high school class IX students whose moral development is more mature than class VII and VIII students, are better able to recognize moral values and morality concepts, and have begun to be able to show behaviors that are more moral in daily life, including one example is opposing and avoiding academic cheating.

Some factors that can influence students to commit academic fraud according to Davis, Drinan, \& Gallant 
(2009) are: there are certain situations that make students feel the need to cheat; there is involvement in groups of students who often cheat together in the classroom; the feeling of fear of failure; stress and pressure in meeting parents' demands for high grades; internal factors in the individual, such as the level of intelligence, motivation, and the need for recognition; and external factors such as classroom conditions that are not conducive, dislike for teachers, and others.

If these factors are related to the results of the study, then grade VII students who are just a few while attending the learning process in junior high school, still adjusting to their school environment, have not been burdened with heavy tasks or demands in the learning process, are still in the introduction stage and adjusting to classmates, still very eager to follow the learning process, and still very obedient to the rules and words of the teacher, it is very natural to have an attitude against academic cheating.

Unlike the conditions in grade VII students, class IX students who have been faced with graduation exams and examinations to enter the next level of education are more vulnerable to feeling depressed over demands arising from within themselves and others and a feeling of fear of failure in facing exams. In addition, the friendship between them has been very closely intertwined and they also feel the need to work together to save themselves from the bad possibilities that occur in the test. If these things are related to the factors that influence the emergence of academic cheating in students, then it is not natural if grade IX students in general have a justifying attitude towards academic cheating.

In Law No.20 of 2003 Article 3, it is said that national education functions to develop capabilities and shape the character and civilization of a dignified nation in the context of educating the life of the nation, aiming at developing the potential of learners to become human beings who believe in and fear God Almighty, noble, healthy, knowledgeable, capable, creative, independent, and become citizens who are democratic and responsible.

If it is associated with educational goals as stated in Law No. 20 of 2003, with the results of research that prove that in general students have an attitude of justification for academic cheating and the higher level of their class, they actually justify the existence of academic cheating, it can be said that the educational goals have not been fully achieved. In addition, the results of the study also indicate that education in Indonesia currently has not succeeded in producing honest people.

\section{Attitudes towards Academic Cheating based on Orientation of Learning Objectives}

The results of data processing attitudes towards academic cheating seen from the orientation of students learning goals indicate that students with mastery learning goals orientation is 83,170 , included in the category of justifying the existence of academic cheating. That means, it can be concluded that in general students who have mastery learning goal orientation, have a justifying attitude towards academic cheating. However, if you look at the grade level, it is different from students in class VIII and IX whose average value is greater than 82.353 , the average value obtained by class VII students is 78.977 and smaller than 82.353. That means, in general students of class VII who have mastery learning goal orientation, have a defiant attitude towards academic cheating. Thus, it can be said that the higher the level of education changes its direction, from opposing academic cheating to justifying.

Table 3

Attitudes towards Academic Cheating based on Orientation of Learning Objectives

\begin{tabular}{|l|c|c|c|c|c|}
\hline \multirow{2}{*}{ Class } & \multicolumn{2}{|c|}{ Performance } & \multicolumn{2}{c|}{ Mastery } & Sig. \\
\cline { 2 - 6 } & Mean & Std. Dev & Mean & Std. Dev & \\
\hline VII & 95,961 & 2,71 & 78,977 & 9,30 & 0,000 \\
\hline VIII & 95,031 & 7,30 & 84,029 & 9,10 & 0,000 \\
\hline IX & 93,924 & 8,31 & 86,661 & 7,64 & 0,012 \\
\hline Tot. & 95,046 & 6,19 & 83,170 & 9,26 & 0,000 \\
\hline
\end{tabular}

Furthermore, the average value of total attitudes toward academic cheating of students who have orientation toward learning performance goals is 95,046. This figure is well above 82,353, and is included in the category of justifying academic cheating. Even if you look at the grade level, the average grades of students in grades VII, VIII, and IX who have an orientation toward learning performance are both well above the 82,353. From these data, it can be concluded that in general students who have orientation toward learning performance also have a justifying attitude towards academic cheating, but with a much higher level.

Whether or not there are differences in attitudes toward significant academic cheating between students who have mastery learning goal orientation and overall performance as well as viewed grade level can be seen from the significance value in Table 3 . From the table, either seen as a whole or grade level view, it is known that all significant values indicate a number less than 0.050 . That is, both viewed as a whole or seen grade level, there are differences in attitudes toward significant academic cheating between students who have mastery learning goals orientation and performance.

Students with an orientation toward learning performance goals tend to be more justified towards academic cheating, and are identified as having a higher tendency to take these actions compared with students who have mastery learning goals orientation. Furthermore, judging from the overall standard deviation rate or grade level, it is known that attitudes toward academic cheating in students who have a goal of performance learning orientation are more equal and uniform than attitudes toward academic cheating in students who have mastery learning goal orientation.

According to Pintrich, Smith, Garcia, \& McKeachi (in Sutetyo \& Kumara, 2012), the orientation of each individual's learning goals influences the individual's learning process as seen from the self-regulation and learning strategies used. Furthermore, Stipek (in Santrock, 2007) explained that individuals with an orientation to the goal of learning performance are not sure of their success in overcoming a problem. When they do not succeed in doing something, they will consider the failure as evidence of the lack of ability they have. This can lead to a number of negative behaviors aimed at protecting themselves from short-term incompetent assumptions, but 
which adversely affect their learning processes and achievements in the long term, such as adopting subtle strategies aimed at protecting their self-image such as looking for- look for reasons or set unrealistic goals; afraid to try new things that he did not believe were successful; and display academic cheating behavior.

The explanation is in line with the results of research conducted on students. This study proves that students who have a goal of learning performance orientation tend to be more justifying acts of academic fraud and are identified as having a high tendency to carry out these actions. It is very possible they do it in order to get high grades so that other students, teachers, or their parents see that they are students who are smart and excel in school.

Davis, Drinan, \& Gallant (2009) explained that several factors that could influence students to commit academic cheating include the pressure to meet the demands of parents to obtain high grades, the fear of failure, the motivation of students who are more externally, and there is a need for recognition. If examined further, several factors that can influence students in committing academic cheating are in line with the characteristics possessed by individuals with orientation to learning performance goals according to Ormrod (2000).

Some characteristics of individuals with orientation to performance learning goals that are in line with factors that can influence students to commit academic cheating actions include that students with performance learning orientation goals tend to avoid tasks and actions that make themselves look incompetent such as asking questions, reacting to assignments easy with a feeling of pride, more extrinsically motivated and tend to cheat to get high scores, evaluate their performance in terms of comparison with others, view mistakes as signs of failure, feel satisfied with performance only if successful, and interpret failure as signs of low ability.

If it is associated with the results of research conducted on students, it can be said that it is natural that students who have orientation toward learning performance goals are more justified in the existence of academic cheating and have a high tendency to do so, because seen from their characteristics, participants students with an orientation to the goal of learning performance indeed prioritize achievement in the form of obtaining high scores without being too concerned with understanding and mastery of the material they are studying in order to obtain a positive assessment from classmates, teachers, or parents who still consider that smart students are students who score high in every subject and get good grades in class, and if they cannot achieve this, they feel like a failure.

\section{CONCLUSION}

Based on the findings and discussion of the results of the study, it was concluded that the length of attending education, grade level, and orientation of learning objectives does not guarantee to develop a positive attitude towards academic cheating, which occurs the longer the learning actually justifies the academic cheating behavior. Class VII students with orientation toward learning performance goals tend to have attitudes that justify academic cheating actions than grade VII students with mastery learning objective orientation. Likewise, what happens to students in class VIII and IX. Students who have orientation toward learning performance goals justify the existence of academic cheating and are identified as having a higher tendency to perform these actions compared to students who have mastery learning goals orientation.

\section{REFERENCES}

[1] Anderman, Eric M. and Koenka, Alison C. (2017), The Relation Between Academic Motivation and Cheating, Theory Into Practice, 56:95-102, 2017

[2] Davis, S.F., Drinan, P.F., \& Gallant, T.B. (2009). Cheating in school: what we know and what we can do. UK: WileyBlackwell.

[3] Diego, Leo Andrew B., (2017) Friends with Benefits: Causes and Effects of Learners' Cheating Practices During Examination, IAFOR Journal of Education: Volume 5-Issue 2-summer 2017.

[4] Gardner, W.M., \& Melvin, K.B. (1988). A scale for measuring attitude toward cheating. Bulletin of the Psychonomic Society, 26(5), hlm. 429-432.

[5] Hu, Guangwei and Sun, Xiaoya, (2017), Institutional Policies on Plagiarism: The Case of Eight Chinese Univercities of Foreign Language/Internasional Studies, System, System 66 Journal Homepage, vol. 56 - 68, 2017

[6 Hu, Guangwe $\mathrm{Hu}$ and Lei, Jun, (2016), Plagiarism in English academic writing: A comparison of Chinese university teachers' and students' understandings and stances, System, System 56 Journal Homepage, vol. 107 118,2016

[7] Lambert, E.G., Hogan, N.L., \& Barton, S.M. (2003). Collegiate academic dishonesty revisited: what have we done, how often have they done it, who does it, and why did they do it?. Electronic journal of sociology. 7(4).

[8] Makmun, A.S. (2007). Psikologi pendidikan perangkat sistem pengajaran modul. Bandung: PT. Remaja Rosda Karya.

[9] Ormrod, J.E. (2000). Educational psychology: developing learners, volume 1. California: Merrill.

[10] Sarita and Dahiya, Rajni, (2015), Academic cheating among students: pressure of parents and teachers, International Journal of Applied Research, 1(10): 793-797

[11] Schunk, H.D., Pintrich, P.R., \& Mecce, L.J. (2008). Motivational in education:

[12] theory, research, and application. Ohio: Pearson Press.

[13] Suprayogi, M.N. (2007). Jurnal of psychology. Tazkiya. Jakarta: Fakultas Psikologi UIN Syarif Hdayatullah.

[14] Sutetyo, Y.F., \& Kumara, A. (2012). Orientasi tujuan, atribusi penyebab, dan belajar berdasar regulasi diri. Jurnal Psikologi, 39(1), hlm. 95-111.

[15] Yusuf LN., S. (2003). Pengantar psikologi. Bandung: DPPB FIP UPI. 